MIDPI sciforum
MOL2NET 2021, International Conference on Multidisciplinary Sciences CHEMBIOMOL-07: Chem. Biol. \& Med. Chem. Workshop, Bilbao, SpainRostock, Germany- Galveston, USA, 2021

\title{
Patentability of hydrogels as biocompatible coatings for medical device biofabrication
}

\author{
Ahmed Fatimi ${ }^{a, b}$ \\ ${ }^{a}$ Department of Chemistry, Polydisciplinary Faculty, Sultan Moulay Slimane University, P.O.BOX \\ 592 Mghila, Beni-Mellal 23000, Morocco \\ ${ }^{b}$ Biological Engineering Laboratory, Faculty of Sciences and Technologies, Sultan Moulay Slimane \\ University, P.O.BOX 523 Mghila, Beni-Mellal 23000, Morocco
}

Graphical Abstract
$\begin{aligned} & \text { Abstract } \\ & \text { This work in the form of patentability study } \\ & \text { presents the state of the art by introducing what } \\ & \text { has been innovated and patented in relation to } \\ & \text { hydrogel coatings. Furthermore, a detailed } \\ & \text { analysis of the patentability of hydrogel appli- } \\ & \text { cations such as in the coating of medical devic- } \\ & \text { es to enhance its clinical performance, have } \\ & \text { been provided by determining publication } \\ & \text { years, inventors, applicants, owners, jurisdic- } \\ & \text { tions and classifications. } \\ & \text { Keywords: patentability; hydrogel coatings; } \\ & \text { medical devices; biofabrication; patent data. }\end{aligned}$

\section{Introduction}

There are a variety of hydrogels commonly used as coatings for medical device applications. The device coating process involving the deposition of hydrogels to the device surface to enhance its performance, particularly, through promotion of osseointegration, haemocompatibility, lubricity and resistance to biofouling. Hydrogels are synthetic matrices made up of a network of hydrophilic polymers that absorb water and/or biological fluids. They can be created from a large number of water-soluble materials including synthetic polymers and biopolymers. The 3D structure of these hydrogels is due to crosslinking which forms an insoluble macromolecular network in the environmental fluid. Research on hydrogels as biocompatible coatings is developing rapidly through the innovation and improvement of raw materials (polymers), chemical synthesis and methods of preparation, as well as formulations and fabrication process. This trend is justified by the several advantages that hydrogels offer for biofabrication and biomedical applications [1-12]. 


\section{Resources and research methods}

The supported field codes used in this study was based on the Patentscope search service of the World Intellectual Property Organization (WIPO) [13,14] and the Lens patent data set [15]. During the search, different keywords and related terms were used and patents were searched according to title, abstract and claims. The search was then filtered to include only documents with the application date until December 31 ${ }^{\text {st }}, 2020$.

\section{Analysis of the patentability of hydrogel coatings}

After the search, 8,184 patent documents have been found. Generally, it encompasses patent applications and granted patents. For relation to hydrogel coatings the found patent documents are classed as: 5,821 patent applications and 2,363 granted patents.

The date on which a patent document is published, thereby making it part of the state of the art. For hydrogel coatings, 8,184 patent documents have been found until 2020. The year $1990 \mathrm{knew}$ the registration of 38 patent documents only, however the year 2020 recorded 791 patent documents. The maximum of patent applications (383) was recorded in 2018, and the maximum of granted patents applications (129) was recorded in 2013. Furtherer, the year 2016 was the year with the maximum patent documents with 459 (Figure 1).

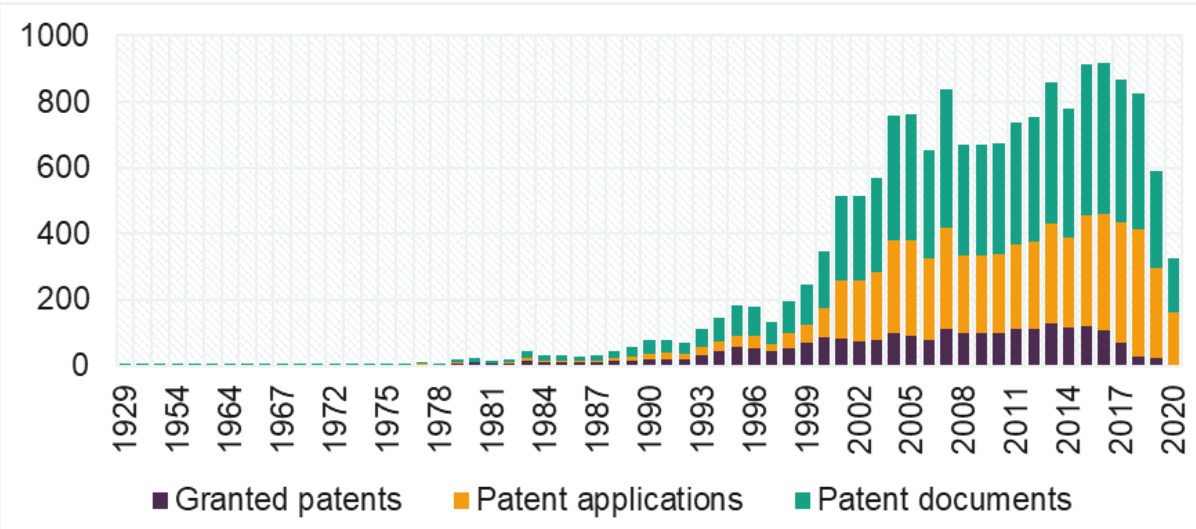

Figure 1. Evolution of patent documents (patent applications and granted patents) as a function of published date of hydrogel coatings.

The inventor is a natural person designated for a patent application. In several cases, the inventor can also be the applicant, as well as there may be more than one inventor per patent application. For hydrogel coatings, the top 10 of inventors until 2020 are presented in Figure 2.
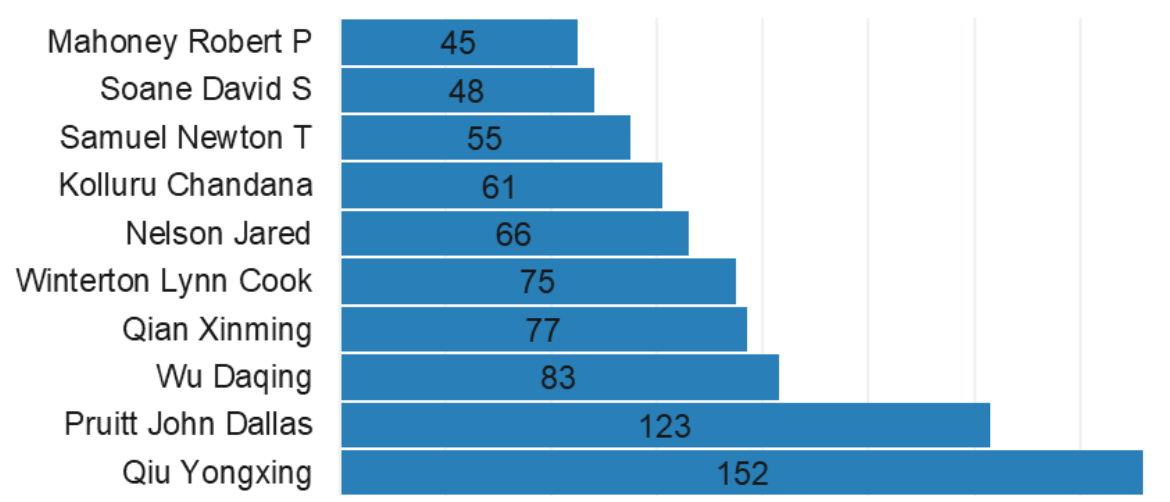

Figure 2. Inventors (top 10) of resulted patent documents of hydrogel coatings. 
The applicant is a person (i.e., natural person) or an organization (i.e., legal entity) that has filed a patent application. In several cases, the applicant can also be the inventor, as well as there may be more than one applicant per patent application. For hydrogel coatings, the top 10 of applicants until 2020 are presented in Figure 3.

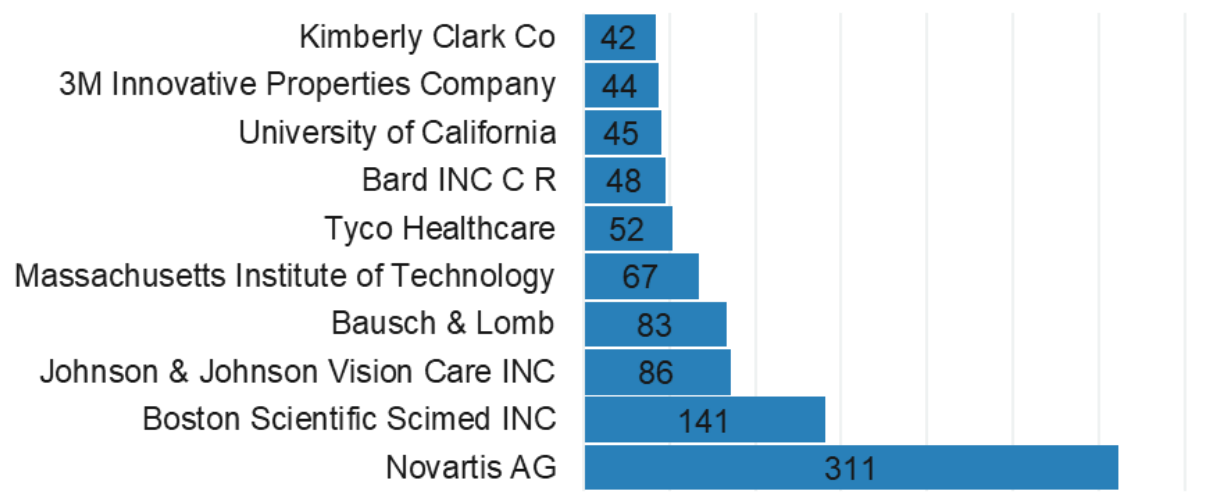

Figure 3. Applicants (top 10) of resulted patent documents of hydrogel coatings.

Assignee or patent owner is a person (i.e., natural person) or an organization (i.e., legal entity) to whom the inventor or applicant assigned the right to a patent. The patent owner has the right, for a period limited to the duration of the patent term to protect his brainchild. The patent system stops others from making, using or selling the invention without his permission or requires others to use the invention under agreed terms with the inventor. For hydrogel coatings, the top 10 of owners until 2020 are presented in Figure 4.

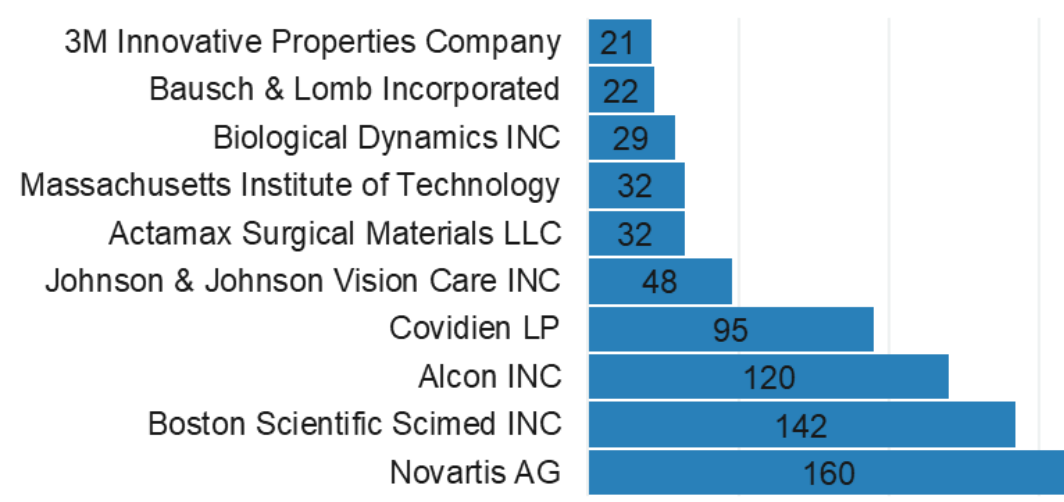

Figure 4. Owners (top 10) of resulted patent documents of hydrogel coatings.

An applicant or first mentioned applicant in case of joint applicants can file application for patent at the appropriate patent office (e.g., Moroccan Office of the Commercial and Industrial Office (OMPIC), United States Patent and Trademark Office (USPTO), China National Intellectual Property Administration (CNIPA), etc.) under whose jurisdiction he normally resides or has his domicile or has a place of business or the place from where the invention actually originated. In case the patent protection is sought in a number of countries worldwide, an applicant may consider filing an international application under the Patent Cooperation Treaty (PCT). It's a global system for filing patent applications administered by the WIPO [16].

The top 10 of jurisdiction of filled patents concerning hydrogel coatings until 2020 are presented in Table 1. 
https://mol2net-07.sciforum.net/

Table 1. Patent contribution (\%) as a function of jurisdiction (top 10) of filled patent applications and granted patents of hydrogel coatings.

\begin{tabular}{|l|c|c|}
\hline \multicolumn{1}{|c|}{ Jurisdiction } & Patent documents & Patent contribution (\%) \\
\hline United States & 4,005 & 49.67 \\
\hline World & 1,938 & 24.04 \\
\hline Europe & 1,040 & 12.90 \\
\hline China & 549 & 6.81 \\
\hline Canada & 165 & 2.05 \\
\hline Republic of Korea & 128 & 1.59 \\
\hline Japan & 94 & 1.17 \\
\hline Australia & 71 & 0.88 \\
\hline Mexico & 41 & 0.51 \\
\hline United Kingdom & 32 & 0.40 \\
\hline
\end{tabular}

The International Patent Classification (IPC) is a hierarchical system in the form of codes, which divides all technology areas into a range of sections, classes, subclasses, groups and subgroups. It is an international classification system that provides standard information to categorize inventions and to evaluate their technological uniqueness [17,18]. For hydrogel coatings, the top 10 of IPC codes until 2020 are presented in Table 2.

Table 2. Meaning of IPC codes concerning the resulted patents of hydrogel coatings [17].

\begin{tabular}{|l|l|c|}
\hline \multicolumn{1}{|c|}{ IPC } & \multicolumn{1}{|c|}{ Description } & $\begin{array}{c}\text { Patent } \\
\text { documents }\end{array}$ \\
\hline A61K9/00 & $\begin{array}{l}\text { Preparations for medical, dental, or toilet purposes. More specifically, me- } \\
\text { dicinal preparations characterized by special physical form. }\end{array}$ & 597 \\
\hline A61L31/10 & Materials for coatings, such as macromolecular materials. & 488 \\
\hline G02B1/04 & $\begin{array}{l}\text { Optical elements characterized by the material of which they are made, } \\
\text { such as optical coatings for optical elements made of organic materials } \\
(\text { e.g., plastics). }\end{array}$ & 465 \\
\hline A61L27/34 & $\begin{array}{l}\text { Materials for prostheses or for coating prostheses containing ingredients of } \\
\text { undetermined constitution or reaction products thereof, such as macromo- } \\
\text { lecular materials. }\end{array}$ & 394 \\
\hline G02C7/04 & $\begin{array}{l}\text { Optical parts characterized by the material of which they are made includ- } \\
\text { ing lenses and lens systems, such as contact lenses for the eyes. }\end{array}$ & 378 \\
\hline A61L31/16 & $\begin{array}{l}\text { Materials for coatings characterized by their function or physical proper- } \\
\text { ties, such as biologically active materials }(e . g ., \text { therapeutic substances). }\end{array}$ & 363 \\
\hline A61L29/08 & $\begin{array}{l}\text { Materials for catheters or for coating catheters, such as materials for coat- } \\
\text { ings. }\end{array}$ & 360 \\
\hline A61L31/14 & $\begin{array}{l}\text { Materials for coatings characterized by their function or physical proper- } \\
\text { ties. }\end{array}$ & 347 \\
\hline A61F2/00 & $\begin{array}{l}\text { Filters implantable into blood vessels and prostheses }(i . e ., \text { artificial substi- } \\
\text { tutes or replacements for parts of the body), such as stents, artificial nails, } \\
\text { dental prostheses, artificial kidneys and artificial hearts. }\end{array}$ & 339 \\
\hline A61L27/52 & $\begin{array}{l}\text { Materials characterized by their function or physical properties, such as } \\
\text { hydrogels or hydrocolloids. }\end{array}$ & 336 \\
\hline
\end{tabular}

\section{Conclusions}

This study of the patentability concerned only the innovation and improvement of hydrogel coatings until 2020. We provided a detailed analysis of the patentability of formulations and process of hydrogel coatings. During our search, we found 8,184 patent documents $(5,821$ patent applications and 
2,363 granted patents). United States was ranked first with 4,005 patent documents and 2016 was the year with the maximum number of patent documents (459).

The innovation and improvement of hydrogel coatings concerned especially raw materials (synthetic and natural polymers), synthesis and methods of preparation, as well as formulations and fabrication process. Based on the patent classification codes, all filled patents and the most inventions intended for medicinal preparations characterized by special physical form and macromolecular materials for prostheses or for coating prostheses, as well as materials for coatings characterized by their function or physical properties including biologically active materials. Knowledge clusters and expert driving factors indicate that the research based on materials characterized by their function or physical properties, such as hydrogels or hydrocolloids is concentrated in the most patents.

\section{Acknowledgments}

The author acknowledges the World Intellectual Property Organization for the Patentscope search service and the Cambia Institute (https://www.lens.org) for The Lens patent data set used in this study.

\section{References}

1. Irwin, N.J.; McCoy, C.P.; Trotter, J.L. Hydrogel Coatings for Medical Device Applications. In Hydrogels: Design, Synthesis and Application in Drug Delivery and Regenerative Medicine, 1st Edition ed.; Singh, T.R.R., Laverty, G., Donnelly, R., Eds.; CRC Press: Boca Raton, 2017; pp. 89-101.

2. Yu, B.; Wang, C.; Ju, Y.M.; West, L.; Harmon, J.; Moussy, Y.; Moussy, F. Use of hydrogel coating to improve the performance of implanted glucose sensors. Biosensors \& bioelectronics 2008, 23, 1278-1284, doi:10.1016/j.bios.2007.11.010.

3. Mattioli-Belmonte, M.; Cometa, S.; Ferretti, C.; Iatta, R.; Trapani, A.; Ceci, E.; Falconi, M.; De Giglio, E. Characterization and cytocompatibility of an antibiotic/chitosan/cyclodextrins nanocoating on titanium implants. Carbohydr Polym 2014, 110, 173-182, doi:10.1016/j.carbpol.2014.03.097.

4. Cleophas, R.T.; Sjollema, J.; Busscher, H.J.; Kruijtzer, J.A.; Liskamp, R.M. Characterization and activity of an immobilized antimicrobial peptide containing bactericidal PEG-hydrogel. Biomacromolecules 2014, 15, 3390-3395, doi:10.1021/bm500899r.

5. Fatimi, A. Chitosan-based embolizing hydrogel for the treatment of endoleaks after endovascular aneurysm repair. International Journal of Polymeric Materials and Polymeric Biomaterials 2019, 68, 107-114, doi:10.1080/00914037.2018.1525729.

6. Fatimi, A.; Tassin, J.F.; Quillard, S.; Axelos, M.A.; Weiss, P. The rheological properties of silated hydroxypropylmethylcellulose tissue engineering matrices. Biomaterials 2008, 29, 533-543, doi:10.1016/j.biomaterials.2007.10.032.

7. Leone, G.; Consumi, M.; Greco, G.; Bonechi, C.; Lamponi, S.; Rossi, C.; Magnani, A. A PVA/PVP hydrogel for human lens substitution: Synthesis, rheological characterization, and in vitro biocompatibility. Journal of biomedical materials research. Part B, Applied biomaterials 2011, 97, 278-288, doi:10.1002/jbm.b.31813.

8. Butruk-Raszeja, B.A.; Lojszczyk, I.; Ciach, T.; Koscielniak-Ziemniak, M.; Janiczak, K.; Kustosz, R.; Gonsior, M. Athrombogenic hydrogel coatings for medical devices--Examination of biological properties. Colloids and surfaces. B, Biointerfaces 2015, 130, 192-198, doi:10.1016/j.colsurfb.2015.04.008.

9. Biazar, E.; Roveimiab, Z.; Shahhosseini, G.; Khataminezhad, M.; Zafari, M.; Majdi, A. Biocompatibility evaluation of a new hydrogel dressing based on polyvinylpyrrolidone/polyethylene glycol. Journal of biomedicine \& biotechnology 2012, 2012, 343989, doi:10.1155/2012/343989. 
10. Mehta, R.I.; Mehta, R.I.; Choi, J.M.; Mukherjee, A.; Castellani, R.J. Hydrophilic polymer embolism and associated vasculopathy of the lung: prevalence in a retrospective autopsy study. Human pathology 2015, 46, 191-201, doi:10.1016/j.humpath.2014.09.011.

11. Nurdin, N.; Weilandt, E.; Textor, M.; Taborelli, M.; Spencer, N.D.; Descouts, P. Reduced frictional resistance of polyurethane catheter by means of a surface coating procedure. Journal of Applied Polymer Science 1996, 61, 1939-1948, doi:10.1002/(SICI)1097-4628(19960912)61:11<1939::AIDAPP8>3.0.CO;2-K.

12. Alloy Welding Processes Ltd. Improvements in or relating to the manufacture of saline flux coating compositions for use in soldering or welding. Granted Patent: GB 314400 A ; Published: Jul 24, 1930 ; Filed: Jun 26, 1929, United Kingdom, 1930.

13. World Intellectual Property Organization. Patentscope. Available online: https://patentscope.wipo.int (accessed on September 2, 2021).

14. World Intellectual Property Organization. Patentscope fields definition. Available online: https://patentscope.wipo.int/search/en/help/fieldsHelp.jsf (accessed on September 2, 2021).

15. Cambia Institute. The Lens Patent Data Set. Available online: https://www.lens.org, Version 8.0.14 (accessed on September 2, 2021).

16. World Intellectual Property Organization. Summary of the Patent Cooperation Treaty (PCT) (1970). Available online: https://www.wipo.int/treaties/en/registration/pct/summary_pct.html (accessed on September 17, 2021).

17. World Intellectual Property Organization. IPC Publication. Available online: https://www.wipo.int/classifications/ipc/ipcpub, IPCPUB v8.5 (accessed on September 2, 2021).

18. World Intellectual Property Organization. Guide to the International Patent Classification (IPC). Available online: https://www.wipo.int/edocs/pubdocs/en/wipo_guide_ipc_2020.pdf (accessed on September 2, 2021). 